\title{
THE CORONAVIRUS PANDEMIC AND ITS IMPACT ON BIHOR COUNTY EXPORT ORIENTED COMPANIES
}

\author{
Adrian Negrea $^{1}$ \\ Ciprian Beniamin Benea ${ }^{2}$ \\ Csaba Bekesi ${ }^{3}$
}

DOI: https://doi.org/10.31410/LIMEN.2020.85

\begin{abstract}
In order to protect the health of their citizens, many governments decided to take a huge risk in implementing lockdowns all over the world, knowing how much it could affect the economy. The thought that choosing the most direct measure to cope with the pandemic in order to save their populations was one of the hardest and the governments cannot be blamed for it. The paper moves forward to correlate the links between mass shut downs affecting the economy with the effects registered by the export-oriented companies in Bihor County, Romania, and the measures that the Romanian Government took. Based on the data provided by AJOFM, the Bihor county employment agency, for the following months - March, April, May, several factors like the number of companies in export-oriented industries, the number of employees, the amount of money that the Government paid, will be analyzed.
\end{abstract}

Keywords: Coronavirus, Enterprises, Foreign trade.

\section{INTRODUCTION: THE CORONAVIRUS PANDEMIC AND ITS IMPACT ON BIHOR COUNTY ECONOMIC ACTIVITY - MEASURES AND IMPLICATIONS}

I $\mathrm{n}$ order to protect the health of their citizens, many governments decided to take a huge risk in implementing lockdowns all over the world, knowing how much it could affect the economy. The thought that choosing the most direct measure to cope with "evil" in order to save their populations was one of the hardest and the governments cannot be blamed for it. No medical system in the world was capable of dealing with such a number of infected people with COVID-19 or any other disease at the same time, and neither were any of the medical systems in the world capable of taking care of their patients with other medical records, so in order for lives to be saved, in this case, the economy had to take the hit.

Correlating the links between mass shut downs affecting the world economy with the effects registered by the industry and unemployment rate in Romania and making a few economic predictions based on the information gathered, the paper moves forward to observe the evolution of the same macroeconomic indicators at a smaller scale, meaning in Bihor County. Based on the data provided by AJOFM, the Bihor county employment agency, for the following months - March, April, and May, several factors will be analyzed that determined the Bihor county companies with foreign trade activities to temporarily suspend their activity and work contracts for their own employees. One factor analyzed follows the typology of companies that have either reduced their foreign trade activity or have completely suspended their activity, in terms of their size: micro-enterprises, small enterprises, medium-sized

University of Oradea, Strada Universității nr. 1, Oradea 410087, Romania

University of Oradea, Strada Universității nr. 1, Oradea 410087, Romania

Bihor County Employment Agency (AJOFM), Oradea, Romania 
enterprises, large enterprises. This factor leads to the following one which analyzes whether there is a temporal difference in the temporary or total activity suspension between enterprises with a single foreign customer compared to those that produce for several customers. The next factor analyzed concerns the period in which companies start asking for help and registering all their employees for technical unemployment or only partially reducing their activity.

The following CAEN codes have been selected because they represent the main industrial production activities correlated with export operations:

- 13 Manufacture of textiles,

- 14 Manufacture of clothing,

- 16 Woodworking, manufacture of wood and cork products, except furniture; manufacture of articles of straw and plaiting materials,

- 20 Manufacture of chemicals,

- 22 Manufacture of rubber and plastic products,

- 24 Metallurgical industry

- 26 Manufacture of computers and electronic and optical products,

- 27 Manufacture of electrical equipment,

- 28 Manufacture of machinery equipment,

- 30 Manufacture of other means of transport,

- 31 Manufacture of furniture,

- 32 Other industrial activities.

After determining which are the main export-oriented sectors of industrial production, the paper goes on to the next step determining the relevant data and examining the number of companies that operate in these sectors and the total number of employees that they have.

In Table 1 below, based on the data provided by AJOFM, at 31.12.2019, the companies were classified by the number of employees in four categories: between 0-9, between 10-49, between 50-249 and over 250. The picture for the 11 export-oriented industrial sectors stands like this: 1.122 companies are operational and they employ almost 23.000 people. The vast majority of companies are SMEs; the classification below shows that there are 860 micro-companies, 188 small companies, 60 medium companies and 14 big companies.

Table 1. Companies classification based on SMEs standards, the number of companies and the number of employees at 31.12.2019

\begin{tabular}{|l|c|c|c|c|c|c|c|c|c|c|c|c|}
\hline & 13 & 14 & 16 & 20 & 22 & 24 & 26 & 27 & 28 & 31 & 32 & $\begin{array}{c}\text { Total } \\
\text { Companie } \\
\text { s }\end{array}$ \\
\hline Between $0-9$ & 34 & 195 & 172 & 21 & 150 & 22 & 16 & 9 & 19 & 115 & 107 & 860 \\
\hline Between $10-49$ & 12 & 46 & 29 & 6 & 38 & 2 & 2 & 3 & 8 & 22 & 20 & 188 \\
\hline $\begin{array}{l}\text { Between } 50- \\
249\end{array}$ & 4 & 23 & 1 & 2 & 10 & 1 & 2 & 3 & 1 & 9 & 4 & 60 \\
\hline Over 250 & 0 & 1 & 0 & 0 & 3 & 0 & 3 & 1 & 1 & 4 & 1 & 14 \\
\hline Total Companies & 50 & 265 & 202 & 29 & 201 & 25 & 23 & 16 & 29 & 150 & 132 & 1122 \\
\hline Total Employees & $\begin{array}{c}65 \\
9\end{array}$ & $\begin{array}{c}394 \\
6\end{array}$ & $\begin{array}{c}117 \\
1\end{array}$ & $\begin{array}{c}33 \\
1\end{array}$ & $\begin{array}{c}434 \\
0\end{array}$ & $\begin{array}{c}27 \\
9\end{array}$ & $\begin{array}{c}510 \\
9\end{array}$ & $\begin{array}{c}67 \\
0\end{array}$ & $\begin{array}{c}89 \\
3\end{array}$ & $\begin{array}{c}412 \\
7\end{array}$ & $\begin{array}{c}131 \\
9\end{array}$ & 22844 \\
\hline
\end{tabular}

Source: Data provided by AJOFM. Disclosures were being requested in order not to give companies names and the amount of government help they received. 
The main export oriented sectors are 14 manufacture of clothing, 22 manufacture of rubber and plastic products, 31 manufacture of furniture. For sector 14 - manufacture of clothing Romania had a competitive advantage after the year 2000, but after that lost it compared to other countries in Asia. This particular sector had a positive result in the trade balance, adding each year after 2000 only trade surpluses. The same thing can be said for sector 31 - manufacture of furniture.

Even though at the end of 2019 things were relatively stable and the first two months of 2020 brought a steady output increase, nobody believed that the Coronavirus pandemic will hit the economy with such fierce and would create havoc in the future.

Table 2. Total number of suspended working contracts and total value in RON of awarded benefits at 31.06.2020 for all the companies in Bihor County

\begin{tabular}{|l|c|c|}
\hline & $\begin{array}{c}\text { Total number of suspended working } \\
\text { contracts }\end{array}$ & $\begin{array}{c}\text { Total Value in RON of } \\
\text { awarded benefits }\end{array}$ \\
\hline March & 16.432 & 8.672 .823 \\
\hline April & 37.625 & 61.866 .592 \\
\hline May & 32.173 & 44.213 .216 \\
\hline
\end{tabular}

Source: Data provided by AJOFM. Disclosures were requested in order not to give companies names and the amount of government help they received.

The measures taken by local and governmental officials through AJOFM came in support and relieve the financial burden for the affected companies and sectors. In Table 4 the consequences of local and governmental officials through AJOFM actions can be seen. If in March only 16.432 got their contracts suspended and AJOFM paid 8.672.823 RON, in April and May the picture gets gloomier. The number of suspended contracts rise to 37.625 and the economic relief to $61.866 .592 \mathrm{RON}$, an increase of more than $700 \%$. In May things appear better, but still severe, with 32.173 suspended contracts and a cost of 44.213.216 RON for the government.

In March a lot of European countries started to impose lockdowns, and basically hit the exportoriented sectors of Bihor County. The table of March total lockdowns of non-essential economic activities in the West is as follows: 11.03.2020 Italy, 14.03.2020 Spain, 15.03.2020 Romania, 16.03.2020 Austria, 17.03.2020 Ireland, 18.03.2020 Belgium and Denmark, 22.03.2020 Germany, 24.03.2020 Britain and Portugal.

Since the four main export partners of Romania imposed lockdowns on non-essential economic activities, what can be seen in Table 3 is the result of early lockdowns on several exportoriented sectors that were feeling the first early signs of a consumption contraction in the West.

Since the lockdowns started after the middle of March, the results are encouraging, since only 72 companies asked for governmental help in supporting the cost with suspended employees' contracts. But at a closer look, even if the figures are low, three sectors suffer the brunt of consumption contraction in the West and at home, being 14 manufacture of clothing, 22 manufacture of rubber and plastic products, 31 manufacture of furniture. These sectors show signs of distress because the big companies and the medium ones that employ $20 \%$ of staff for sector 14 , and more than $50 \%$ for sector 22 and respectively 31 , are affected.

This is only the gathering of the clouds because the economic storm is at the corner for the world economy, but also the case study at hand: Bihor County. 
In Table 3 which comprises the available economic dates for all the sectors in April and May shows the real extent that the lockdowns created. It is a fiasco for local and national officials that see the staggering number of companies that have suspended contracts and asked for government help.

Table 3. The number of companies that received governmental help at 31.06.2020

\begin{tabular}{|c|c|c|c|c|c|c|c|c|c|c|c|c|}
\hline \multicolumn{13}{|c|}{ March } \\
\hline CAEN code & 13 & 14 & 16 & 20 & 22 & 24 & 26 & 27 & 28 & 31 & 32 & Total \\
\hline $\begin{array}{l}\text { Companies that } \\
\text { applied for } \\
\text { government } \\
\text { subsidies }\end{array}$ & 3 & 17 & 6 & 2 & 16 & 2 & 0 & 3 & 0 & 11 & 12 & 72 \\
\hline $\begin{array}{l}\% \text { of companies } \\
\text { that applied for } \\
\text { government } \\
\text { subsidies from the } \\
\text { total }\end{array}$ & $6 \%$ & $6 \%$ & $3 \%$ & $7 \%$ & $8 \%$ & $8 \%$ & $0 \%$ & $19 \%$ & $0 \%$ & $7 \%$ & $9 \%$ & $6 \%$ \\
\hline $\begin{array}{l}\text { Employees with } \\
\text { suspended } \\
\text { contracts }\end{array}$ & 10 & 268 & 92 & 16 & 1117 & 7 & 0 & 83 & 0 & 1543 & 341 & 3477 \\
\hline $\begin{array}{l}\% \text { of Employees } \\
\text { with suspended } \\
\text { contracts from the } \\
\text { total }\end{array}$ & $2 \%$ & $7 \%$ & $8 \%$ & $5 \%$ & $26 \%$ & $3 \%$ & $0 \%$ & $12 \%$ & $0 \%$ & $37 \%$ & $26 \%$ & $15 \%$ \\
\hline Subsidies & 3710 & 114974 & 44096 & 12385 & 322395 & 2933 & 0 & 33594 & 0 & 814125 & 127053 & 1475265 \\
\hline $\begin{array}{l}\% \text { of subsidies } \\
\text { from the total }\end{array}$ & $0 \%$ & $1 \%$ & $1 \%$ & $0 \%$ & $4 \%$ & $0 \%$ & $0 \%$ & $0 \%$ & $0 \%$ & $9 \%$ & $1 \%$ & $17 \%$ \\
\hline \multicolumn{13}{|c|}{ April } \\
\hline CAEN code & 13 & 14 & 16 & 20 & 22 & 24 & 26 & 27 & 28 & 31 & 32 & Total \\
\hline $\begin{array}{l}\text { Companies that } \\
\text { applied for } \\
\text { government } \\
\text { subsidies }\end{array}$ & 22 & 61 & 31 & 7 & 57 & 3 & 3 & 4 & 3 & 37 & 60 & 288 \\
\hline $\begin{array}{l}\text { \% of companies } \\
\text { that applied for } \\
\text { government } \\
\text { subsidies from the } \\
\text { total }\end{array}$ & $44 \%$ & $23 \%$ & $15 \%$ & $24 \%$ & $28 \%$ & $12 \%$ & $13 \%$ & $25 \%$ & $10 \%$ & $25 \%$ & $45 \%$ & $26 \%$ \\
\hline $\begin{array}{l}\text { Employees with } \\
\text { suspended } \\
\text { contracts }\end{array}$ & 224 & 1138 & 258 & 46 & 2377 & 18 & 262 & 196 & 19 & 2596 & 622 & 7756 \\
\hline $\begin{array}{l}\% \text { of Employees } \\
\text { with suspended } \\
\text { contracts from the } \\
\text { total }\end{array}$ & $34 \%$ & $29 \%$ & $22 \%$ & $14 \%$ & $55 \%$ & $6 \%$ & $5 \%$ & $29 \%$ & $2 \%$ & $63 \%$ & $47 \%$ & $34 \%$ \\
\hline Subsidies & 356152 & 1415008 & 444458 & 84336 & 4643036 & 21415 & 271129 & 337921 & 41175 & 4464762 & 1183032 & 13262424 \\
\hline $\begin{array}{l}\% \text { of subsidies } \\
\text { from the total }\end{array}$ & $1 \%$ & $2 \%$ & $1 \%$ & $0 \%$ & $8 \%$ & $0 \%$ & $0 \%$ & $1 \%$ & $0 \%$ & $7 \%$ & $2 \%$ & $21 \%$ \\
\hline \multicolumn{13}{|c|}{ May } \\
\hline CAEN code & 13 & 14 & 16 & 20 & 22 & 24 & 26 & 27 & 28 & 31 & 32 & Total \\
\hline $\begin{array}{l}\text { Companies that } \\
\text { applied for } \\
\text { government } \\
\text { subsidies }\end{array}$ & 21 & 56 & 30 & 6 & 53 & 3 & 3 & 4 & 2 & 32 & 59 & 269 \\
\hline $\begin{array}{l}\% \text { of companies } \\
\text { that applied for } \\
\text { government } \\
\text { subsidies from the } \\
\text { total }\end{array}$ & $42 \%$ & $21 \%$ & $15 \%$ & $21 \%$ & $26 \%$ & $12 \%$ & $13 \%$ & $25 \%$ & $7 \%$ & $21 \%$ & $45 \%$ & $24 \%$ \\
\hline
\end{tabular}




\begin{tabular}{|l|c|c|c|c|c|c|c|c|c|c|c|c|}
$\begin{array}{l}\text { Employees with } \\
\text { suspended } \\
\text { contracts }\end{array}$ & 150 & 736 & 202 & 36 & 2014 & 177 & 425 & 185 & 12 & 1931 & 607 & 6475 \\
\hline $\begin{array}{l}\% \text { of Employees } \\
\text { with suspended } \\
\text { contracts from the } \\
\text { total }\end{array}$ & $23 \%$ & $19 \%$ & $17 \%$ & $11 \%$ & $46 \%$ & $63 \%$ & $8 \%$ & $28 \%$ & $1 \%$ & $47 \%$ & $46 \%$ & $28 \%$ \\
\hline Subsidies & 178510 & 793325 & 239903 & 47962 & 3221803 & 228057 & 348935 & 242321 & 32761 & 2135424 & 746253 & 8215254 \\
\hline $\begin{array}{l}\% \text { of subsidies } \\
\text { from the total }\end{array}$ & $0 \%$ & $2 \%$ & $1 \%$ & $0 \%$ & $7 \%$ & $1 \%$ & $1 \%$ & $1 \%$ & $0 \%$ & $5 \%$ & $2 \%$ & $19 \%$ \\
\hline
\end{tabular}

Source: Data provided by AJOFM. Disclosures were requested in order not to give companies names and the amount of government help they received

The data for March indicates a completely different story when it comes to percentages. If the 3 sectors seem severely affected only by looking at the number of affected companies when the focus shifts towards to percentages, the sector 27 Manufacture of electrical equipment is the worst affected, where over $19 \%$ of companies in this sector have decided to suspend employment contracts and ask for governmental help. If the focus remains at the same percentage, especially at \% of employees with suspended contracts from the total, there is a noticeable shift that, although the percentage of companies in sectors 22 manufacture of rubber and plastic products, 31 manufacture of furniture, 32 other industrial activities, does not exceed $10 \%$; when it comes to the suspension of employment contracts, the percentages are: $26 \%$ for sector $22,37 \%$ for sector 31 and respectively $26 \%$ for sector 32 .

Most of the subsidies in March went to sector 31 manufacture of furniture, obtaining RON 814,125 , representing approximately $9 \%$ of the total subsidies granted in that month. The total subsidies granted to the exporting companies represented $17 \%$ of the total subsidies for March. At a time when the evolution of the pandemic imposed harsh measures of total lockdown in most countries of Europe and given the fact that European markets are the main markets for Romanian products, the effects are obvious.

April 2020 is the first month of the year in which the devastating effects of the imposed draconian measures could be felt. All the figures in Table 3 are getting worse. The number of companies applying for state subsidies and sending employees into technical unemployment is raising. In all sectors analyzed, at least a tripling of the numbers of companies requesting aid can be observed. If the percentages are being analyzed, they reflect the same worrying trend of companies resorting to government aid. The highest percentage increase of employees that are sent into technical unemployment is also driven by the sectors 22 manufacture of rubber and plastic products, 31 manufacture of furniture, 32 other industrial activities, where the percentages are $55 \%$ for sector $22,63 \%$ for sector 31 and $47 \%$ respectively for sector 32 , totaling approximately 5500 employees whose employment contracts have been suspended.

May does not show a significant improvement in terms of reducing the number of companies in need of government assistance. The trend is maintained and is similar to the previous month, both in terms of the number of companies, percentages, number of employees and grants received. There is also a positive evolution of the reduction of contracts sent for financing by companies, from over 7700 in April to about 6500 in May. The improvement in export activity can be seen, for example, in sector 31 manufacture of furniture, where the number of employees with suspended employment contracts is reduced from 2569 people to 1931 employees. This reduction of around 600 contracts may also lead to a stronger restart of this sector due to the increase in consumption in Western European countries. Probably the pandemic and the 
obligation to stay locked in a house or apartment aroused the desire of people to improve their personal comfort and make purchases of the new furniture.

\section{CONCLUSION}

From the economical point of view, some businesses had to cut off staff, some of them even closed due to the Coronavirus pandemic; it is clear that it has already affected Bihor County entire export-oriented sectors like 14 manufacture of clothing, 22 manufacture of rubber and plastic products, 31 manufacture of furniture, 32 other industrial activities which were hit and forced to suspend contracts for their employees, causing further supply chain disruption and ultimately a decrease in demand.

The proactive measures taken by the government in order to support the financial relief of companies with their workers will be seen at the beginning of 2021. If the Western economies bounce back to the consumption level before the pandemic, the feeling is that companies from the 11 export-oriented sectors from Bihor County will further produce vendible goods.

\section{REFERENCES}

AJOFM Bihor, statistical data accessed at 20th July 2020

Institutul Național de Statistică, https://insse.ro/cms/ro/tags/comunicat-indicii-productieiindustriale accessed at 20th July 2020

Institutul Naţional de Statistică, https://insse.ro/cms/ro/tags/comunicat-comenzi-noi-dinindustrie accessed at 20th July 2020, dates available until March 2020

Institutul Național de Statistică, https://insse.ro/cms/ro/tags/comunicat-somaj-bim accessed at 20th May 2020 